\title{
Metabolic correction for attention deficit/hyperactivity disorder: A biochemical-physiological therapeutic approach
}

\section{${ }^{1}$ Mikirova NA, ${ }^{1}$ Rogers AM, ${ }^{1}$ Taylor PR, ${ }^{1}$ Hunninghake RE, ${ }^{2}$ Miranda-Massari JR, and ${ }^{3}$ Gonzalez MJ}

${ }^{1}$ Riordan Clinic, 3100, N Hillside, Wichita, KS, USA; ${ }^{2}$ Department of Practice, School of Pharmacy, Medical Sciences Campus, University of Puerto Rico, San Juan, Puerto Rico;

${ }^{3}$ Nutrition Program, Department of Human Development, School of Public Health, Medical Sciences Campus, University of Puerto Rico, San Juan, Puerto Rico

Corresponding author: Miranda-Massari JR, PharmD, Department of Practice, School of Pharmacy, Medical Sciences Campus, University of Puerto Rico, PO Box 365067 San Juan, PR 00936-5067

Submission date: November 21, 2012, Acceptance date: January, 23, 2013; Publication date: January, 27, 2013

\begin{abstract}
Objective: This investigation was undertaken to determine the reference values of specific biochemical markers that have been have been associated with behavior typical of ADHD in a group of patients before and after metabolic correction.
\end{abstract}

Background: Attention deficit hyperactivity disorder (ADHD) affects approximately two million American children, and this condition has grown to become the most commonly diagnosed behavioral disorder of childhood. According to the National Institute of Mental Health (NIMH), the cause of the condition, once called hyperkinesis, is not known.

The cause of ADHD is generally acknowledged to be multifactorial, involving both biological and environmental influence. Molecular, genetic, and pharmacological studies suggest the involvement of the neurotransmitter systems in the pathogenesis of ADHD. Polymorphic variants in several genes involved in regulation of dopamine have been identified, and related neurotransmitter pathways alterations are reported to be associated with the disease.

Nutritional deficiencies, including deficiencies in fatty acids (EPA, DHA), the amino acid methionine, and the trace minerals zinc and selenium, have been shown to influence neuronal function and produce defects in neuronal plasticity, as well as impact behavior in children with attention deficit hyperactivity disorder.

Materials/Methods: This study was based on data extracted from our patient history database covering a period of over ten years. We performed laboratory tests in 116 patients 2.7-25 years old with a diagnosis of ADHD. Sixty-six percent $(66 \%)$ of patients were males. Patients were 
followed from 3 month to 3 years. We compared the distributions of fatty acids, essential metals, and the levels of metabolic stress factors with established reference ranges before and after interventions. In addition, we analyzed the association between toxic metal concentrations and the levels of essential metals.

Results: This study was based on data extracted from our patient history database covering a period of over ten years. We performed laboratory tests in 116 patients 2.7-25 years old with a diagnosis of ADHD. Sixty-six percent $(66 \%)$ of patients were males. Patients were followed from 3 month to 3 years. We compared the distributions of fatty acids, essential metals, and the levels of metabolic stress factors with established reference ranges before and after interventions. In addition, we analyzed the association between toxic metal concentrations and the levels of essential metals. According to these data, the metabolic correction of ADHD by supplementation with minerals, vitamins, essential fatty acids, and amino acids can ameliorate ADHD symptoms. Eighty percent $(80 \%)$ of children who were treated from several weeks to 1-2 years, demonstrated improvement of metabolic stress level, measured by pyrroles. For these patients the levels of EPA were increased and the omega-6/omega-3 ratio was improved.

Conclusion: In the studied population it was demonstrated that metabolic correction of biochemical disturbances using essential fatty acids, amino acids, and minerals can improve fatty acid profiles and metabolic stress levels. These disturbances or variations from reference values have been associated with behavior typical of ADHD. Further studies need to be conducted with integrative metabolic correction therapy to determine its value in the management of ADHD.

Key words: Attention deficit hyperactivity disorder, metabolic correction, fatty acid composition, essential metals, toxic metals, pyrroles, vitamins and minerals.

\section{BACKGROUND:}

According to the National Institute of Mental Health, attention deficit hyperactivity disorder (ADHD) affects approximately two million American children; 3 to 5 percent of the school-age population, and is about four times more common in boys than in girls [1-4]. Over the past several decades this condition has grown to become the most commonly diagnosed behavioral disorder of childhood. According to NIMH, the cause of the condition, once called hyperkinesis, is not known.

ADHD is primarily characterized by a persistent pattern of inattention and/or hyperactivityimpulsivity that is more frequent and severe than is typically observed in individuals at a comparable level of development [5,6]. The cause of ADHD is generally acknowledged to be multifactorial, involving both biological and environmental influences [7]. Molecular, genetic, and pharmacological studies suggest the involvement of the dopaminergic, serotonergic, and noradrenergic neurotransmitter systems in the pathogenesis of ADHD. Polymorphic variants in several genes involved in regulation of the dopamine have been identified and related neurotransmitter pathways alterations are reported to be associated with the disease [8-9]. 
Nutritional deficiencies, including deficiencies in the long chain polyunsaturated fatty acids (PUFA) eicosapentaenoic acid (EPA; 20:5n-3) and docosahexaenoic acid (DHA; 20:6n-3), the amino acid methionine, and the trace minerals zinc and selenium, have been shown to influence neuronal function and produce defects in neuronal plasticity, as well as impact behavior in children with attention deficit hyperactivity disorder. Neurons lacking in plasticity are a factor in neurodevelopmental disorders such as ADHD, autism, and mental retardation. Essential nutrients help maintain normal neuronal plasticity. Among dietary factors, learning and behavior are influenced not only by nutrients, but also by exposure to toxic food contaminants such as lead, mercury, arsenic, and aluminum that can disrupt metabolic processes and alter neuronal plasticity. Toxic heavy metals are found in the air we breathe, the food we eat, and the houses we live in. Toxic metal exposure can result in a wide array of common mental health disorders. The results of studies demonstrate that there are neurochemical and behavioral consequences of heavy metal exposure during brain development.

In addition, nutritional deficiencies and toxic metal exposure have been shown not only to alter neuronal function, but to increase metabolic stress among children with autism. These factors may be directly related to the development of behavior disorders and learning disabilities.

The role of n-3 PUFA's in child mental health has received recent attention related to the treatment of attention-deficit hyperactivity disorder. The association between EFA and hyperactivity was initially hypothesized in the 80's [10]. This hypothesis is compatible with lower blood EFA fractions in children with ADHD compared with matched comparisons. Several recent studies have examined the relation between n-3 PUFAs and children's behavioral problems, depressed mood, and clinical depression [13-16]. The fatty acids that are biologically relevant for mental health include the long-chain n-3 FAs that are present in cell membranes in the brain and neural tissue, namely docosahexaenoic acid and eicosapentaenoic acid. Although the exact mechanisms by which PUFAs, especially DHA and EPA, affect behavioral disorders such as ADHD remain unclear, plausible evidence suggests why DHA and EPA may be involved in these disorders. DHA and EPA are important for both membrane fluidity and neurotransmitter function, especially synaptic signal transduction, particularly during the perinatal period $[11,12]$. Summary of studies on blood essential fatty acid (EFA) status in children with attention-deficithyperactivity disorder is presented in a review [13]. Cross-sectional studies have reported that the frequency of behavioral problems is inversely associated with n-3 PUFA status $[14,15]$. Several case control studies [16-18] have reported low blood concentrations of DHA and arachidonic acid (AA) in children with ADHD compared with age-sex matched control subjects.

Finally, several recent longitudinal studies found a negative association between DHA status early in life and subsequent behavior problems in young children [19-21]. These data suggest children and adolescents with ADHD continue to display abnormal essential fatty acid profiles that are different from normal controls of similar age, and there are metabolic differences in fatty acid handling between ADHD children and normal controls.

One of the hypotheses that link EFA to ADHD is that children with ADHD might suffer from slower conversion of linoleic acid and alpha linolenic acid to long chain PUFA. A recent genetic study supports this direction [22].

Other studies mounted evidence suggesting a central role for transition bio-metals in the etiopathogenesis of ADHD. Indeed, while studying the molecular basis for this heterogeneous 
group of diseases, it has become increasingly evident that bio-metals and non-physiological metals [23-30] are often involved in pathology onset and progression, either by affecting the conformation of specific proteins or by exacerbating local metabolic stress. For example, the deficiency of zinc, which is involved in the production and modulation of melatonin, is considered to be a factor in ADHD [31-33]. Zinc is an essential co-factor of more than 100 enzymes, including metalloenzymes, which are necessary in the metabolism of carbohydrates, fatty acids, proteins, and nucleic acids. It is an important factor in the metabolism of neurotransmitters, prostaglandins, and for maintaining brain structure and function.

In a study [34], it was shown that red cell magnesium $(\mathrm{Mg})$ concentrations of ADHD children were below a critical value of $2.2 \mathrm{mmol} / \mathrm{L}$. In addition $\mathrm{Mg}$ depletion has long been known to cause hyperexcitability with convulsive seizures in rodents [35]. Metabolic disorders and genetic alterations are suspected in this pathology, in which $\mathrm{Mg}$ transport and intracellular distribution may be reduced and can be reversed by treatment [36, 37]. In addition, $\mathrm{Mg}$ is involved in control of some CNS processes.

Many treatment methods of ADHD have been tried, with the most common approach being psychiatric intervention and use of prescription drugs such as methylphenidate (Ritalin) with mixed results and an array of multiple side-effects.

The purpose of this study is to evaluate if the metabolic correction of pathologic biochemical-physiological disturbances associated with ADHD can be resolved by administering target nutrients.

\section{METHODS:}

ADHD diagnosis was made by qualified medical doctors, based on direct observation plus reports by multiple sources (parents and other caretakers).

Laboratory tests were done and analyzed for 116 patients 2.7-25 years old (mean age 12 years old). Thirty-four $\%$ of patients were females and $66 \%$ males. Patients were followed from 3 months to two-three years.

The protocol for patients with ADHD included evaluations of fatty acid composition, essential metals, toxic metals (in blood and hair), food allergies, levels of urinary pyrroles, and the levels of vitamins before, during, and post treatment.

For all patients, we compared the distributions of fatty acids, essential metals, and the levels of metabolic stress factors with established reference ranges for these parameters. In addition, we analyzed the association between toxic metal concentrations and the levels of essential metals.

\section{Treatment and follow-up}

Children and adolescents were administered an integrative protocol for ADHD treatment, similar to a protocol developed by Gant [38-40]. This treatment of ADHD is based on the metabolic correction of biochemical abnormalities associated with ADHD. This safe, evidence based approach gives the patient an opportunity to respond prior to considering more toxic pharmaceutical approaches. The treatment includes supplementation with minerals, vitamins, omega-3 and omega-6 essential fatty acids, flavonoids, probiotics, dietary modifications, and chelation of toxic metals by natural substances. 


\section{Statistical methods/data collection}

This study was not a controlled experiment, but rather a mining of data from our patient history database covering a period of over ten years.

For statistical analysis Systat software (Systat, Inc) and Kaleidagraph software were used. Variables were presented as mean values $\pm \mathrm{SD}$, or as medians with corresponding 25th percentiles. Association between different factors was assessed using linear models and polynomial model. Statistical significance was accepted if the null hypothesis could be rejected at $\mathrm{p} \leq 0.05$.

\section{RESULTS:}

The analysis of the imbalances and deficiencies found for this group of patients is presented below.

\section{Laboratory tests of patients with ADHD Essential fatty acids}

The fatty acids of interest for our analysis were the n- 6 and n-3 PUFA. In particular, the fatty acids linoleic acid (18:3n-6, LA) and alpha-linolenic acid (18:3n-3, ALA) are called essential fatty acids (EFA) as they cannot be synthesized by the human body and, therefore, have to be provided by the diet. The other $\mathrm{n}-3$ and $\mathrm{n}-6$ fatty acids can be synthesized by humans from LA and ALA, respectively.

As it was previously mentioned, the imbalance of fatty acids, reduction in essential metals, increased level of toxic metals, and augmented level of stress are the characteristics and, probably, underlined primary causes of the ADHD condition. Many studies have shown that omega-3 fatty acid deprivation during development results in altered performance in learning tasks, altered activity of membrane receptors and proteins, and altered metabolism of several neurotransmitters including dopamine. Relevant studies suggest that omega-3 fatty acids deficiency decreases the mean cell body size of neurons in the hypocampus, hypothalamus, and cortex [13]. Lower levels of omega-3 fatty acids correlate with a higher score on the behavioral scale for patients with ADHD [18].

Data presented in Table 1 are baseline and show the mean and SD of the percentage of fatty acids, reference range (RR), and percentage of patients with higher and lower level of EFA than reference range.

Analyzed distribution of docosahexaenoic acid (22:6n-3, DHA) for patients with ADHD demonstrated that the $16 \%$ of the patients had the levels of this fatty acid lower than reference range (mean-2SD) and for $40 \%$ of patients the level of DHA was less than average value of RR.

The DHA has an important structural role: it comprises $10 \%$ to $20 \%$ of human brain total fatty acid composition, and it is the most predominant $n-3$ fatty acid found in the brain. DHA is important for both membrane fluidity and neurotransmitter function, especially synaptic signal transduction.

Summary of the relative plasma fatty acid composition in patients with ADHD is presented in Table 1. 
Table 1. Relative plasma fatty acid composition in patients with ADHD

\begin{tabular}{|l|l|l|l|l|l|l|}
\hline \multicolumn{7}{|c|}{ Relative plasma fatty acid composition in patients with ADHD } \\
\hline Fatty acid & Mean (\%) & $\begin{array}{l}\text { Standard } \\
\text { Deviation }\end{array}$ & $\begin{array}{l}\text { Double } \\
\text { bond }\end{array}$ & $\begin{array}{l}\text { Refence range } \\
(\% \text { of total })\end{array}$ & $\begin{array}{l}\text { Higher } \\
\text { than RR }\end{array}$ & $\begin{array}{l}\text { Lower } \\
\text { than RR }\end{array}$ \\
\hline n-3 series & & & & & & \\
\hline alpha linolenic & 0.15 & 0.05 & $18: 3 \mathrm{n}-3$ & $0.1-0.2$ & & $55 \%$ \\
\hline Eicosapentaenoic (EPA) & 0.38 & 0.21 & $20: 5 \mathrm{n}-3$ & $0.3-0.6$ & & $16 \%$ \\
\hline Docosahexaenoic (DHA) & 3.00 & 0.25 & $22: 6 \mathrm{n}-3$ & $2.0-5.9$ & & $42 \%$ \\
\hline total omega 3 & 3.90 & 1.95 & & $3.0-5.0$ & & \\
\hline omega 6 series & & & & & & \\
\hline Arachidonic & 14.09 & 1.98 & $20: 4 \mathrm{n}-6$ & $12.0-17.0$ & & \\
\hline Dihomogammalinolenic & 1.62 & 0.46 & $20: 3 \mathrm{n}-6$ & $1.0-2.0$ & & \\
\hline Gamma-linolenic & 0.05 & 0.04 & $18: 3 \mathrm{n}-6$ & $0.04-0.07$ & & \\
\hline Linoleic & 11.34 & 1.70 & $18: 2 \mathrm{n}-6$ & $9-14$ & & \\
\hline ratios & & & & & $50 \%$ & \\
\hline AA/EPA & 20.77 & 13.04 & & & $1.5-8$ & \\
\hline omega6/omega3 & 8.14 & 3.63 & & & \\
\hline
\end{tabular}

Deficits in the frontal cortex dopamine neurotransmission seen in patients with ADHD could be associated with lower brain DHA concentration. Low DHA status is associated with poor development of visual acuity and low indices of neural development in human infants.

The eicosapentaenoic acid (20:5n-3, EPA) is also an $n-3$ long-chain fatty acid that is less abundant in neural (membrane) structures, but has numerous roles in neural, enzymatic, and antiinflammatory functions. The distribution of this fatty acid in ADHD patients is presented in Figure 1 (bar shows the reference range estimated from the same age population without ADHD). According to these data $50 \%$ of patients had a level of EPA lower than reference range.

In addition, the ratio of arachidonic acid to EPA demonstrated the abnormal distribution in patients with ADHD. In the n-6 family, arachidonic acid (20:4n-6, AA) is an important structural lipid in the neural membranes. According to the previous studies, the arachidonic acid to eicosapentaenoic acid ratio in blood correlates positively with clinical symptoms of depression, bipolar affective disorder, and reactive depression.

Our analysis of patients with ADHD demonstrated that there was increased level of this ratio that supports the presence of stress in patients with ADHD conditions. Reference range of the ratio $\mathrm{AA} / \mathrm{EPA}$ is between 5 and 13. Distribution of this ratio for patients showed that $70 \%$ of children and adolescents had ratio levels higher than the normal range. This result provides a basis for the nutritional supplementation of subjects with ADHD, aimed at reducing the AA/EPA ratio. 
Figure 1. Distribution of eicosapentaenoic fatty acid in plasma of patients with ADHD before treatment.

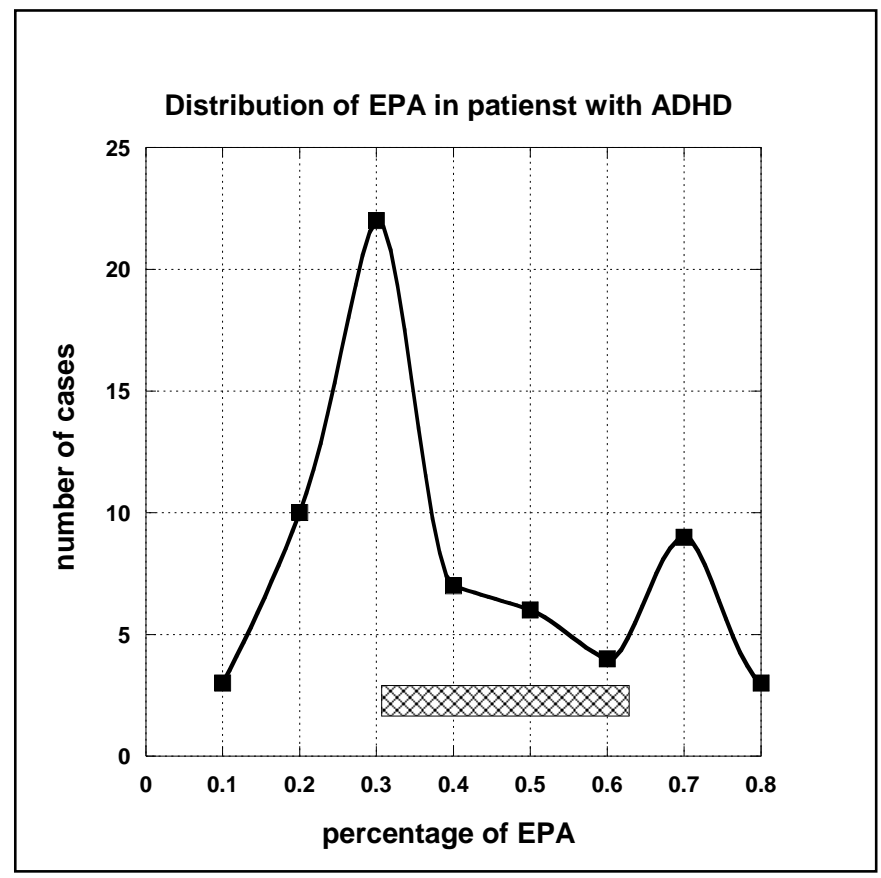

The analysis of the data of fatty acids in omega 6 series showed that children with ADHD have lower levels of EFAs in omega-6s in addition to omega-3s.

Regarding the omega 6 fatty acids, gamma-linolenic acid (GLA) was significantly lower in patients with ADHD (Figure 2).

Figure 2. Distribution of gamma-linolenic acid in plasma of patients with ADHD before intervention.

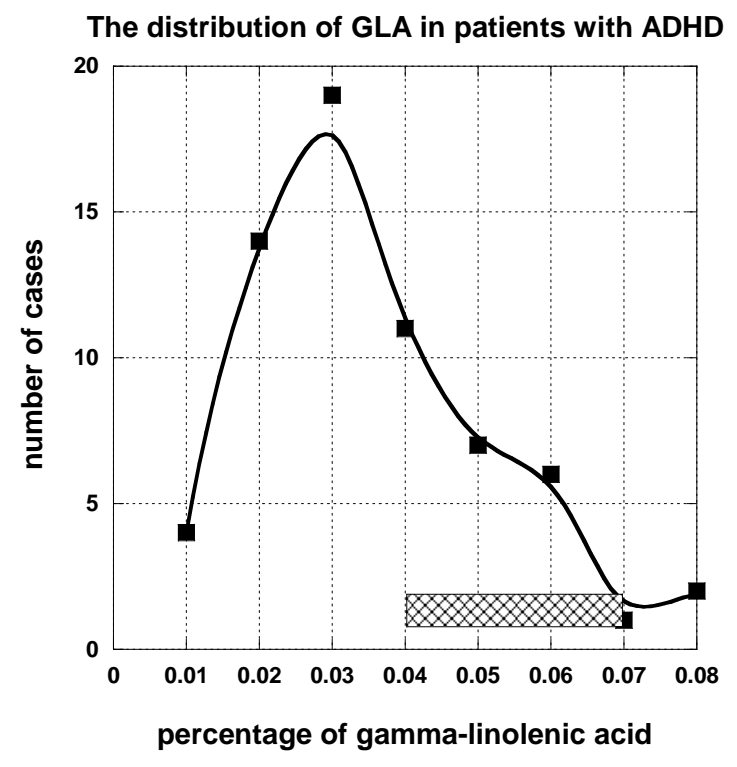


As GLA is an $n-6$ fatty acid that has anti-inflammatory properties, the decreased level of this fatty acid can lead to increased level of inflammation in patients with ADHD.

Excessive amounts of omega-6 polyunsaturated fatty acids and a very high omega-6/omega3 ratio was also measured for patients with ADHD.

Our analysis demonstrated that for patients with ADHD there were higher levels of omega 6 and lower level of omega 3 fatty acids (Figure 3). Maximum of the ratio distribution was in the range of $9-10$ and $50 \%$ of patients had omega6/omega3 levels higher than 8 .

Figure 3. Omega-6 to omega-3 ratio measured in plasma of patients with ADHD before treatment.

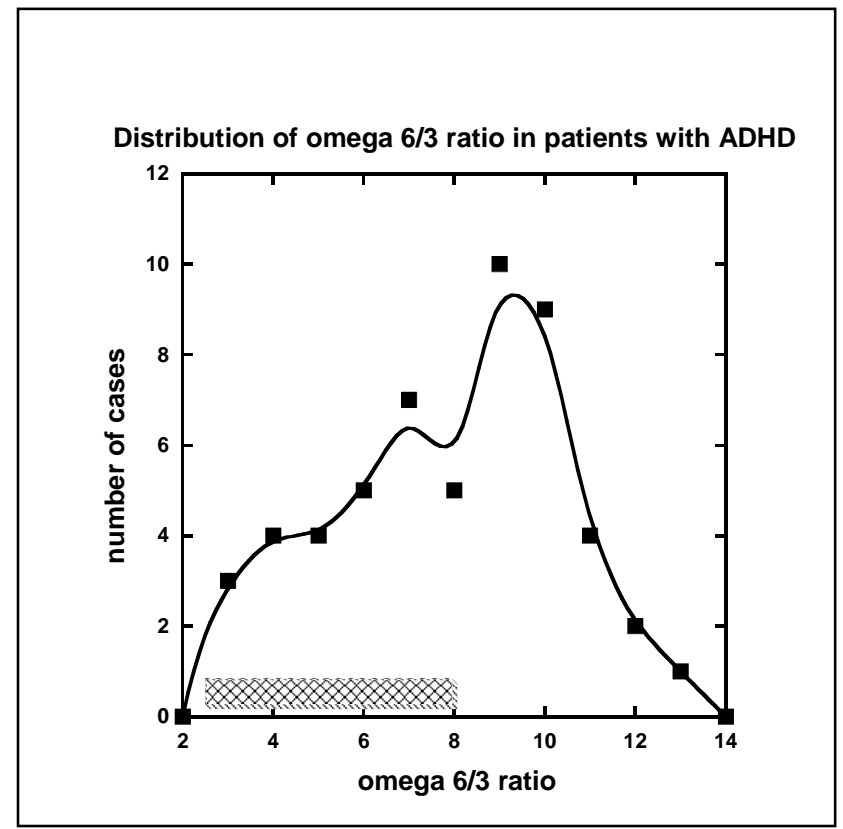

\section{Urinary pyrroles in patients with $A D H D$}

Pyrroles or "Mauve Factor," a metabolic product of hemoglobin, was first detected in the urine of psychiatric patients by the Hoffer group in 1958 and named for its appearance on paper chromatograms. Irvine extracted the compound from urine, correctly assigned the structure to the pyrrole family, and conferred the common name [40-42]. Hoffer observed that recovery from acute schizophrenia, associated with disappearance of Mauve from the urine, regression with reappearance [43-48]. Large doses of vitamin B6 suppressed Mauve in schizophrenics. Later it became clear that Mauve is not confined to schizophrenia. Mauve elevation is documented in many cognitive, affective, and neurobehavioral disorders. According to the studies [45] elevated levels of pyrroles can be found in patients with schizophrenia (59\%-80\%), depression (12\%$46 \%$ ), autism (46\%-48\%) and ADHD (40\%-47\%). Combined treatment by vitamin B6 and zinc suppressed Mauve and improved symptoms in many neurobehavioral disorders.

Despite that the high level of pyrroles was described in the urine of patients with various mental illnesses, how pyrroles are produced and appear in the urine is still unclear. Pyrrole is from subclass of monopyrroles, well known for biotoxicity, and an elevated level of excretion classically associated with emotional stress. The suggestion is that the pyrroles in urine may be the result of an aberration of porphyrin metabolism (in conditions of iron deficiency, unstable 
hemoglobin disease, RBC hemolysis, or others). The test of pyrroles or HPL (hydroxyhemopyrrolin-2-one) assay is based on the extraction of pyrroles from urine with chloroform followed by reaction with Ehrlich's acid aldehyde reagent $(0.5 \mathrm{~g}$ of $\mathrm{p}$ dimethylaminobenzaldehyde, $2.5 \mathrm{ml}$ sulfuric acid in $50 \mathrm{ml}$ of methanol). This preparation yields a chromophore with an absorption maximum of $540 \mathrm{~nm}$. For this test, urine samples of patients with ADHD were collected and 200-500 mg of ascorbic acid was added as a preservative $(2.0 \mathrm{ml}$ of urine for analysis).

The level of pyrroles was measured in 116 patients. Sixty-five $\%$ of the patients had a level of pyrroles higher than upper normal limit $(20 \mathrm{ug} / \mathrm{dL})$. The highest level was measured for a 10year old boy $(481 \mathrm{ug} / \mathrm{dL})$. A level of $192 \mathrm{ug} / \mathrm{dL}$ was found in 5 year old girl and levels of $123 \mathrm{ug} / \mathrm{dL}$ and $114 \mathrm{ug} / \mathrm{dL}$ in two boys.

We analyzed a correlation between the levels of pyrroles and histamine. Histamine is an important brain neurotransmitter and neuro-regulator that is present in all nerve cells. Degradation of histamine is through methylation; low histamine levels indicate over-methylation and high histamine level means that the process of re-methylation is overactive. Histamine either directly or indirectly influences all other major neurotransmitters, often via inhibition of neurotransmitter release thus theoretically causing anxiety, depression, or both. The anxiety may be caused by histamine's inhibition of GABA, which slows nerve transmission. Histamine can also release norepinephrine, thus potentially causing anxiety.

Histamine imbalance exists in patients with mental disorders. Patients with a mental disorder may have higher than normal and lower than normal levels of histamine. Histapenia describes the low histamine conditions and histadelia is term for elevated histamine.

The level of histamine was screened for patients with ADHD. Maximum of the distribution of histamine was on the upper level of the reference range (RR), which is $60 \mathrm{ng} / \mathrm{ml}$, and half of the subjects had a level of histamine higher than the upper level of the RR.

Distribution of the values of pyrroles for patients with ADHD is presented in Figure 4.

Figure 4. Distribution of the levels of pyrroles in urine of patients with ADHD before intervention

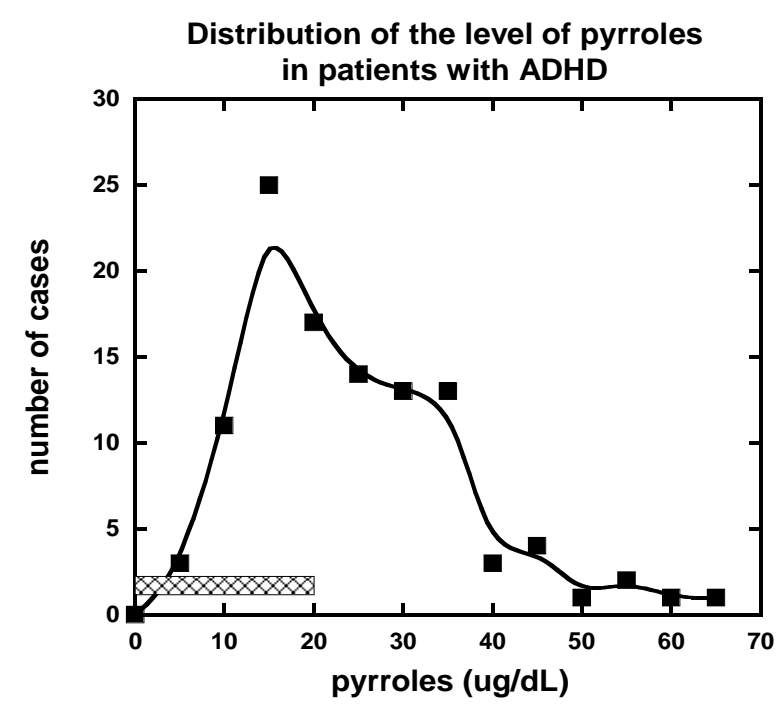


We found histamine imbalances in these patients, and two different tendencies in the relations between the levels of histamines and pyrroles. For patients with a mild increase in the level of pyrroles (values less than $45 \mathrm{ug} / \mathrm{dL}$ ), there was inverse association between pyrroles and histamine (Figure 5a). For several patients with very high levels of pyrroles (higher than 45 $\mathrm{ug} / \mathrm{dL}$ ), there was direct correlation between histamine and pyrrole levels (Figure $5 \mathrm{~b}$ ).

Figure $5(\mathbf{a}, \mathbf{b})$. Correlations between the levels of pyrroles and histamine
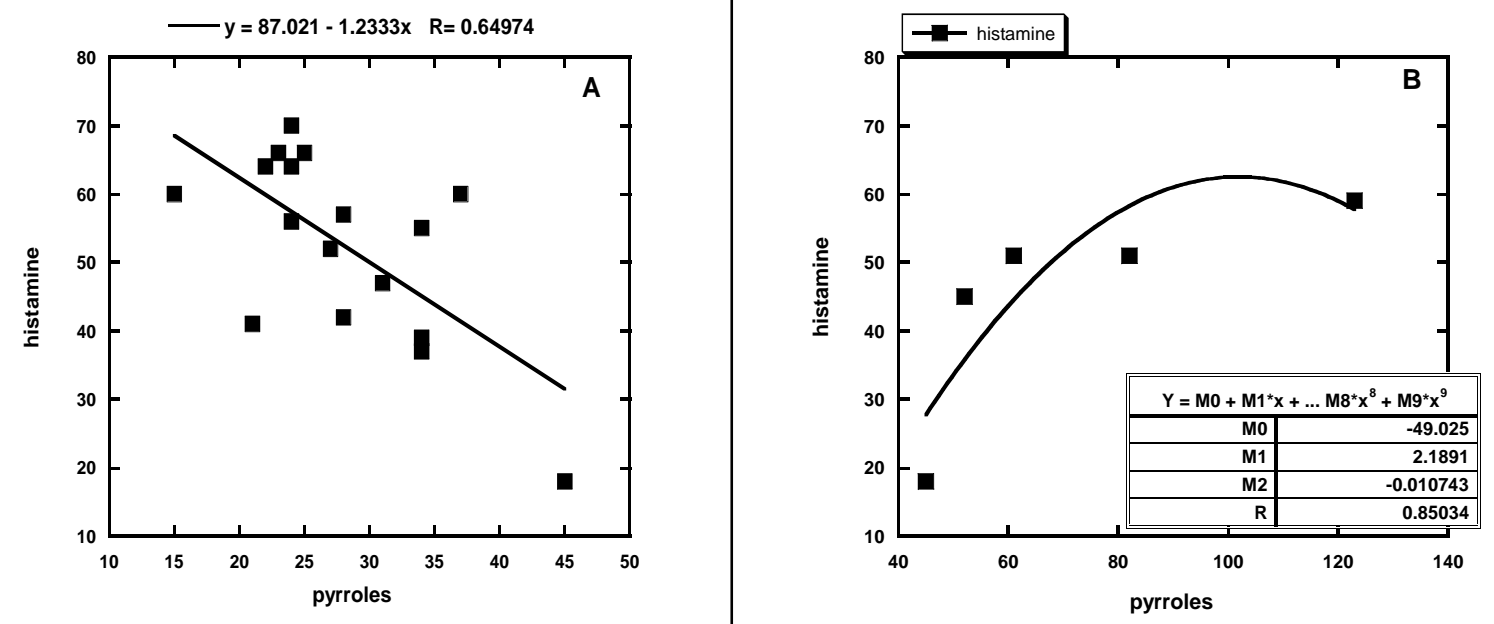

\section{ADHD and the levels of essential and toxic metals}

The measurements of the levels of the essential metals in plasma, red blood cells, and hair were made by clinical laboratory by inductively-coupled plasma-mass spectrometry. Summary of the data is presented in Table 2 .

Table 2. Essential metals in plasma in patients with ADHD

\begin{tabular}{|c|c|c|c|c|c|c|c|}
\hline \multicolumn{8}{|c|}{ Essential metals in plasma in patients with ADHD } \\
\hline Essential metals & $\begin{array}{l}\text { Number of } \\
\text { cases out of } \\
\text { reference } \\
\text { range }\end{array}$ & $\begin{array}{l}\text { Percentage } \\
\text { of patients } \\
\text { lower than } \\
\text { RR }\end{array}$ & $\begin{array}{l}\text { Mean } \\
\text { value }\end{array}$ & Units & SD & $\begin{array}{l}\text { Reference } \\
\text { range }\end{array}$ & $\begin{array}{l}\text { Percentage of } \\
\text { patients higher } \\
\text { than RR }\end{array}$ \\
\hline $\begin{array}{l}\text { magnesium } \\
\text { (hair) }\end{array}$ & $35 / 68$ & $53 \%$ & 34.1 & $\mathrm{ug} / \mathrm{g}$ & 38.5 & $25-90$ & \\
\hline $\begin{array}{l}\text { magnesium } \\
\text { (RBC) }\end{array}$ & $26 / 71$ & $35 \%$ & 5 & $\mathrm{mg} / \mathrm{dL}$ & 0.67 & $4.5-6.4$ & \\
\hline copper (hair) & $36 / 124$ & & 33.2 & $\mathrm{ug} / \mathrm{g}$ & 37.5 & $6-25$ & $\begin{array}{l}37 \% \\
\text { (16 patients) } \\
>80 \text { ug/g }\end{array}$ \\
\hline zinc(hair) & $11 / 68$ & $16 \%$ & 133.5 & $\mathrm{ug} / \mathrm{g}$ & 36.8 & $100-180$ & \\
\hline Zinc (RBC) & $17 / 60$ & $28 \%$ & 10.3 & $\mathrm{ug} / \mathrm{g}$ & 1.9 & $9-15$ & \\
\hline selenium (hair) & $41 / 104$ & $39 \%$ & 2.0 & $\mathrm{ug} / \mathrm{g}$ & 1.4 & $0.2-1.4$ & \\
\hline
\end{tabular}


Several minerals were low in ADHD patients. The most pronounced deficiencies were found for magnesium, selenium, and zinc. Data analysis demonstrated that many children with ADHD have lower zinc in relation to reference range (28\% of patients had levels of zinc in red blood cells lower than RR).

Our data showed a deficiency of magnesium in patients with ADHD. Magnesium is involved in control of some CNS processes. The prior clinical study has been reported on the effect of Mg supplementation on hyperactivity in children.

$\mathrm{Mg}$ deficiencies were indicated by a subnormal concentration of $\mathrm{Mg}$, determined by hair analysis (Figure 6) and red blood cell analysis. Fifty \% of patients according to hair analysis and $35 \%$ of patients according to $\mathrm{RBC}$ analysis had a level of $\mathrm{Mg}$ lower than reference range.

Analysis of the distribution of selenium for these patients also demonstrated that $39 \%$ of patients had the levels of selenium lower than the reference range. Selenium is an important mineral for maintaining proper antioxidant balances, either directly (as an antioxidant itself) or indirectly (via its incorporation into selenium-dependent enzymes). The latter is evidenced by a number of important enzymes such as the dependence of the important antioxidant enzyme glutathione peroxidase on selenium.

Figure 6. Distribution of the magnesium levels in hair of patients with ADHD

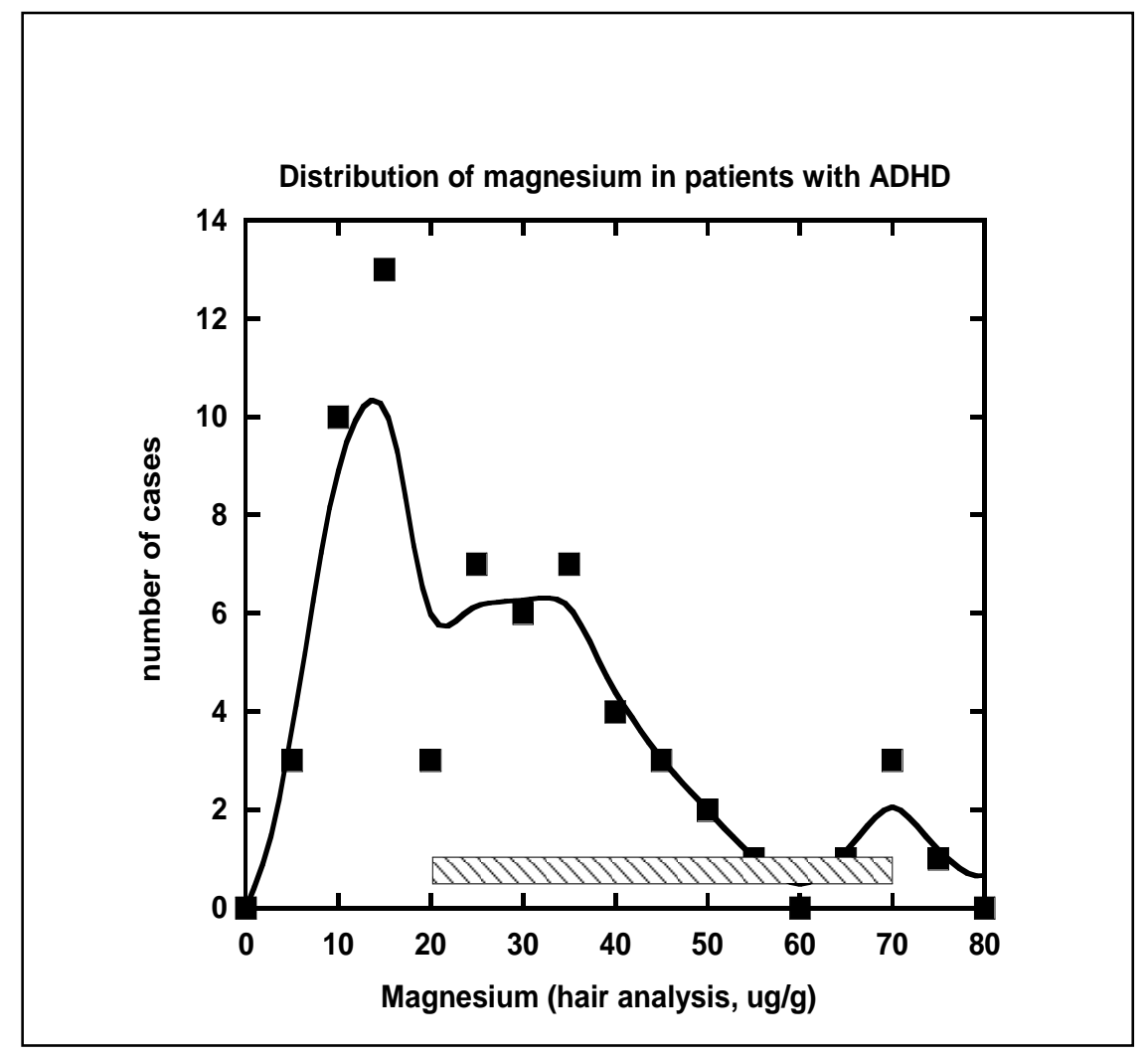

In addition, copper, and zinc participate in SOD enzymatic mechanisms that protect against free radicals, and therefore, serve an important adjunct role in oxidative balance [50]. A diminished level of selenium can indicate an increased level of oxidative stress in these patients. 
In addition to the several essential metals mentioned above, a copper imbalance was found in ADHD children and adolescents. Thirty-seven $\%$ of patients had a level of copper higher than the upper reference level $25 \mathrm{ug} / \mathrm{g}$. Copper interferes with zinc metabolism, affects thyroid activity, and enhances the biogenic amines (the neurotransmitters that stimulate brain activity). Copper appears to have many important functional roles in the body that apparently relate to, among others, the maintenance of the immune function, bone health, and homeostasis [51]. The element is needed in trace amounts, but excess is toxic. It increases lipid peroxidation and depletes glutathione reserves, which makes the organism more vulnerable to oxidative stress. Copper and zinc levels are regulated by metallothionein, a short linear protein composed of 61 amino acid units. When this protein fails to perform its necessary functions, abnormal levels of nutrient metals (such as copper, zinc, and manganese) and toxic metals (such as cadmium, mercury, and lead) can result.

Copper and zinc are in high concentrations in the brain hippocampus. As a result elevated copper and depressed zinc have been associated with hyperactivity, attention deficit disorders, behavior disorders, and depression. It has been suggested that high copper induces damage of dopaminergic neurons through destroying antioxidant defenses, such as it was demonstrated in animal studies by lowering $\mathrm{Cu} / \mathrm{Zn}$ SOD levels in rats [57, 58].

Our results showed the deficiency of zinc in RBCs of $28 \%$ of patients and in hair of $16 \%$ of patients. Several other studies have investigated the role of zinc in the etiology of ADHD and have suggested that zinc deficiency is associated with the pathophysiology of the disease [52-

54]. Research has also demonstrated that zinc treatment may be efficacious for ADHD individuals [55].

We analyzed correlation between depressed level of $\mathrm{Zn} / \mathrm{Cu}$ ratio and increased level of copper in patients with ADHD. The ratio of copper to zinc was chosen as this ratio is clinically more important than the concentration of either of these trace metals. The relationship between $\mathrm{Zn} / \mathrm{Cu}$ and $\mathrm{Cu}$ levels in ADHD individuals showed that the ratios were significantly lower when accompanied by high $\mathrm{Cu}$ levels (all values are measured by hair analysis).

\section{Effect of toxic metals on the levels of essential metals}

Our analysis demonstrated that toxic metals can substitute and deplete essential metals. The concentration of toxic metals measured in patients with ADHD is shown in Table 3.

Examples of the relations between zinc, selenium and the concentration of toxic metals in hair are presented in Figure 7 (a, b) and show that the increased level of toxic metals results in the depletion of essential metals.

As toxic metals have a synergistic effect and lead and mercury have higher toxic effects on cells in the body than do other heavy metals, the total concentration of heavy metals was estimated by summation of all concentrations with multiplication of the concentrations of $\mathrm{Pb}$ and $\mathrm{Hg}$ by a factor of ten. According to the data presented in the figures, high levels of toxic metals resulted in a decrease in the level of zinc and selenium. The same inverse correlation was found for the zinc to copper ratio and the levels of toxic metals. 
Table 3. Concentration of toxic metals measured in patients with ADHD

\begin{tabular}{|c|c|c|c|}
\hline \multicolumn{3}{|c|}{ Concentration of toxic metals measured in patients with ADHD (hair analysis) } \\
\hline Toxic metal & $\begin{array}{l}\text { Average } \\
(\mathrm{ppm})\end{array}$ & SD & Maximum level (ppm) \\
\hline Aluminum & 8.32 & 7.7 & 55 \\
\hline Lead & 1.3 & 1.5 & 9.4 \\
\hline Mercury & 0.42 & 0.34 & 1.8 \\
\hline Arsenic & 0.29 & 0.45 & 2.3 \\
\hline Cadmium & 0.11 & 0.16 & 1.4 \\
\hline
\end{tabular}

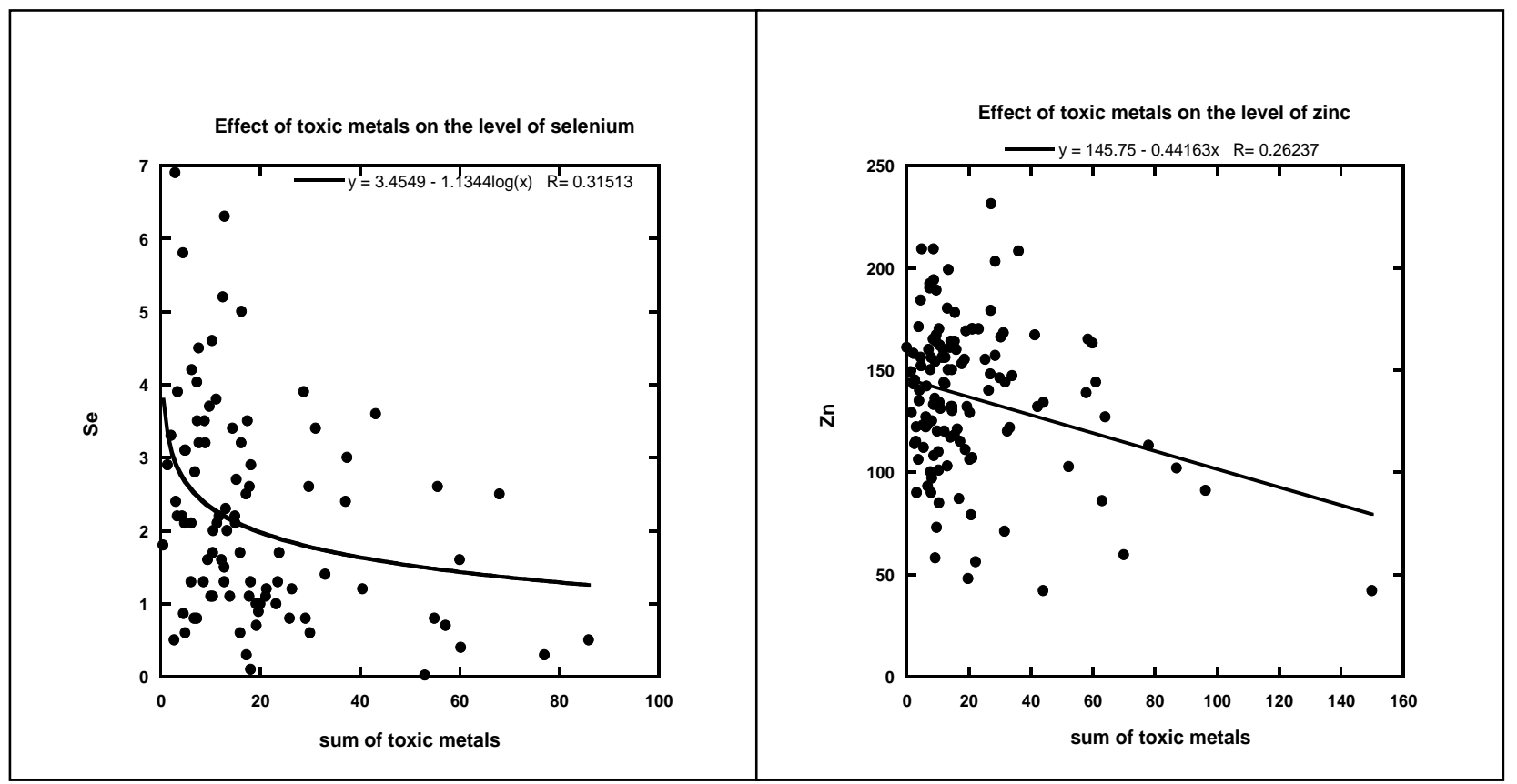

Figure 7 (a, b). Inverse relations between the levels of zinc and selenium in patients with ADHD and accumulated toxic metals in the body

Effect of orthomolecular treatment (metabolic correction) on the level of metabolic stress and fatty acid composition in patients with ADHD

Treatment was performed according to principles of integrative management of this condition, and patients were treated by essential fatty acids, amino acids, minerals, probiotics and vitamins. The list of the medicine (nutraceuticals) that were prescribed in different combination (mixed composition) depending on the laboratory testing of the deficiencies in patients is shown in Table 4. 
Table 4. List of prescribed nutraceuticals.

Patients received only some of these supplements depending of their metabolic profile.

\begin{tabular}{|c|c|c|}
\hline Biotin 5000 Mcg \#60 Caps & Glycine Sticks 30 Sticks & $\begin{array}{l}\text { Pantothenic Acid 500mg- } \\
\# 100\end{array}$ \\
\hline $\begin{array}{l}\text { Bk Currant Seed 500mg \#90 } \\
\text { Softgels }\end{array}$ & Immuno Pro $10.6 \mathrm{Oz}$ & Potassium Gluc 98mg \#100 \\
\hline Borax 100 Tabs & L Tryptophan 60 Caps 500mg & Pro DHA 1000 Mg 60 Tabs \\
\hline Cal/Mag/Zinc \#240 Caps & L-Arginine $500 \mathrm{Mg} \# 100$ & Prodophilus \\
\hline Calcium Gluconate IV 1cc & Latero Flora Caps \#60 & ProEFA-90 Caps 1000mg \\
\hline Captomer $65 \mathrm{Mg}$ \#45 Caps & Lecithin $21 \mathrm{Gr} \# 100$ Softgels & ProEPA 60 Count $1000 \mathrm{mg}$ \\
\hline Catemine (Tyrosine/B6) \#120 & L-Glutamine $500 \mathrm{Mg} \# 90$ Caps & ProOmega Liquid-4 Oz \\
\hline $\begin{array}{l}\text { Co Enzyme Q-10 } 400 \mathrm{Mg} 30 \\
\text { Tabs }\end{array}$ & Lipoic Acid- 100 Mg- 90 Caps & Quercetin/Bromelain \#180 \\
\hline Cod Liver Oil 100 Caps & L-Lysine $500 \mathrm{Mg} \# 50$ & $\begin{array}{l}\text { Selenium- 200mcg- } \# 180 \\
\text { Caps }\end{array}$ \\
\hline DHAJunior-250 mg- 180 Caps & L-Ornithine- 500 MG- 100 Caps & $\begin{array}{l}\text { Solar D Gems } 4000 \text { IU } 120 \\
\text { Caps }\end{array}$ \\
\hline Digestive Enzymes \#250 Tabs & L-Taurine \#100- 500mg & Solution Of Magnesium $8 \mathrm{Oz}$ \\
\hline $\begin{array}{l}\text { DL-Methionine } 500 \mathrm{Mg} \# 250 \\
\text { Caps }\end{array}$ & L-Threonine 500mg- \#100 & $\begin{array}{l}\text { Vit D3-50, 50,000 IU } 100 \\
\text { Caps }\end{array}$ \\
\hline DL-Phenylalanine $500 \mathrm{mg} \# 100$ & L-Tryptophan 500mg \#60 Caps & $\begin{array}{lllll}\text { Vitamin } & \text { A } & 10000 & \text { IU- } 100 \\
\text { Softgels } & & & & \\
\end{array}$ \\
\hline DMG \#60 Tabs & Lutein- 20 Mg- 60 Caps & Vitamin B1 100mg \#100 Caps \\
\hline EnteroPro 60 Caps & $\begin{array}{l}\text { Methylcobalamin 5000mcg } 60 \\
\text { Tabs }\end{array}$ & Vitamin B2 100mg- 100caps \\
\hline $\begin{array}{l}\text { Evening Primrose Oil \#100- } 500 \\
\text { Mg Softgel }\end{array}$ & MSM Powder $200 \mathrm{Gr}$ & $\begin{array}{l}\text { Vitamin B6 (Pyridoxine) IV } \\
\text { Infusion 1cc }\end{array}$ \\
\hline $\begin{array}{l}\text { Flaxseed Oil Cap \#90 } 1000 \mathrm{Mg} \\
\text { Softgel }\end{array}$ & NAC 600 Mg 60 Caps & Vitamin C 1 Gram \#250 \\
\hline Folic Acid-800 mcg- 100 Caps. & Niacin $50 \mathrm{Mg} 300 \mathrm{Tabs}$ & $\begin{array}{l}\text { Vitamin D } 2000 \text { IU-120 Soft } \\
\text { Gels }\end{array}$ \\
\hline Gaba Caps 750 Mg-60 Caps & Niacinamide $50 \mathrm{mg} \# 250$ & Vitamin E 100 IU \#250 \\
\hline Gentle Iron $25 \mathrm{mg} 90$ Caps & Zinc Sulfate IV 10cc & Zinc Boost \\
\hline $\begin{array}{l}\text { Glucosamine Sulf } 500 \mathrm{Mg}-180 \\
\text { Caps }\end{array}$ & & \\
\hline
\end{tabular}


As the result of treatment, there were changes in the balance of omega 6 and omega 3 fatty acids. Data in Figure 8 show the examples of the improvement in the ratio of omega 6/omega 3 after treatment.

Figure 8. Improvement in the ratio of omega 6 to omega 3 fatty acids after treatment

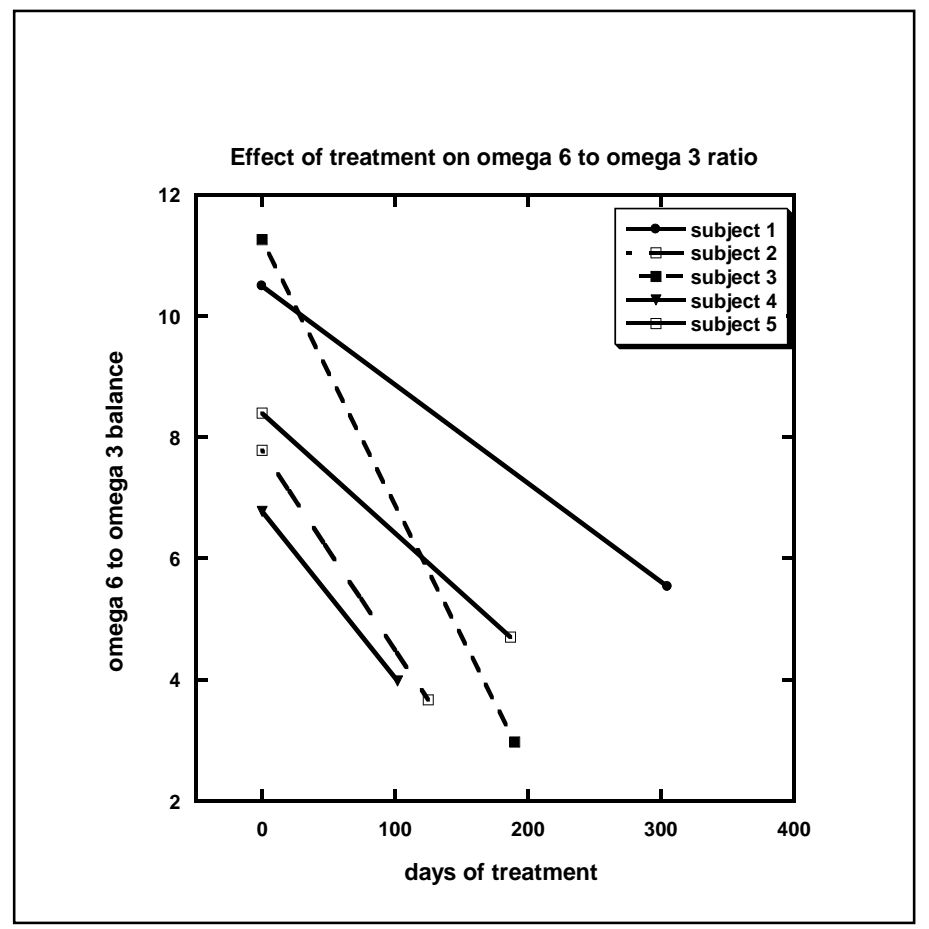

In addition, for patients who had levels of EPA in plasma at the lower level of the reference range $(0.2 \%-0.3 \%)$, these values were increased 2-5 times after 120-500 days of treatment. The level of metabolic stress evaluated by the pyrroles was improved in $80 \%$ of patients (Figure 9).

Figure 9. Percentage of patients demonstrated improvement or progression of the stress levels

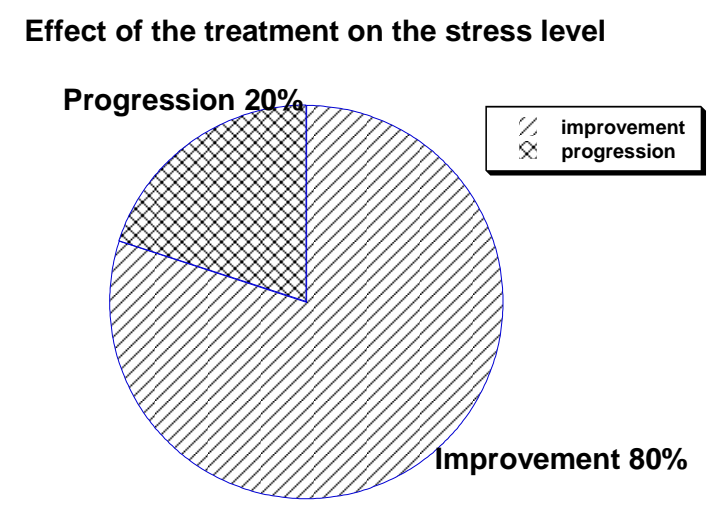


Data of the percentage of improvement in the pyrroles' values (decrease excessive), days of treatment, age and sex of patients are shown in Table 5.

Table 5. Percentage of improvement of the pyrroles' values in patients with ADHD

\begin{tabular}{|l|l|l|l|l|l|l|l|l|l|}
\hline Age & Sex & $\begin{array}{l}\text { Initial } \\
\text { value of } \\
\text { (ug/dL) }\end{array}$ & $\begin{array}{l}\text { Percentage of } \\
\text { improvement }\end{array}$ & $\begin{array}{l}\text { Days of } \\
\text { treatment }\end{array}$ & Age & Sex & $\begin{array}{l}\text { Initial } \\
\text { value of } \\
\text { pyrrole } \\
\text { (ug/dL) }\end{array}$ & $\begin{array}{l}\text { Percentage } \\
\text { improvement }\end{array}$ & $\begin{array}{c}\text { Days of } \\
\text { treatment }\end{array}$ \\
\hline 9.0 & $\mathrm{~F}$ & 48 & 33.33 & 167 & 13.3 & $\mathrm{M}$ & 28 & 50.00 & 127 \\
\hline 8.5 & $\mathrm{~F}$ & 25 & 40.00 & 63 & 15.9 & $\mathrm{M}$ & 26 & 84.62 & 167 \\
\hline 14.7 & $\mathrm{~F}$ & 41 & 53.66 & 95 & 10.2 & $\mathrm{M}$ & 481 & 92.72 & 25 \\
\hline 9.9 & $\mathrm{M}$ & 34 & 52.94 & 80 & 10.3 & $\mathrm{M}$ & 35 & 62.86 & 136 \\
\hline 6.0 & $\mathrm{M}$ & 36 & 27.78 & 141 & 18.9 & $\mathrm{~F}$ & 28 & 42.86 & 63 \\
\hline 7.5 & $\mathrm{M}$ & 34 & -70.59 & 37 & 11.7 & $\mathrm{M}$ & 123 & 50.41 & 26 \\
\hline 8.5 & $\mathrm{M}$ & 26 & 65.38 & 86 & 11.8 & $\mathrm{M}$ & 61 & 68.85 & 102 \\
\hline 7.5 & $\mathrm{M}$ & 112 & 87.50 & 91 & 3.4 & $\mathrm{~F}$ & 28 & 67.86 & 687 \\
\hline 5.1 & $\mathrm{M}$ & 25 & 40.00 & 63 & 7.7 & $\mathrm{M}$ & 25 & -12.00 & 193 \\
\hline 22.8 & $\mathrm{M}$ & 52 & 61.54 & 110 & 7.9 & $\mathrm{~F}$ & 24 & 66.67 & 149 \\
\hline 10.6 & $\mathrm{M}$ & 21 & -66.67 & 78 & 22.4 & $\mathrm{M}$ & 30 & 50.00 & 174 \\
\hline 2.7 & $\mathrm{M}$ & 31 & 38.71 & 379 & 12.8 & $\mathrm{M}$ & 27 & 55.5 & 191 \\
\hline
\end{tabular}

Deficiencies of essential metals such as zinc and magnesium were also improved by the supplementation. Combined magnesium and zinc uptake for 3 to 24 weeks restored normal $\mathrm{Mg}$ and $\mathrm{Zn}$ values in hair and red blood cells.

\section{CONCLUSION:}

According to these data, the metabolic correction of ADHD by supplementation with minerals, vitamins, omega-3/omega-6 essential fatty acids, and amino acids can ameliorate ADHD symptoms. After the intervention, $80 \%$ of children treated from several weeks to 1-2 years, demonstrated an improvement of metabolic stress level measured by level of pyrroles. For these patients the levels of EPA were increased and the ratio omega6/omega 3 was improved.

Putting all data together, it was demonstrated that after consumption of a combination of fatty acids as well as magnesium and zinc, amino acids, vitamins and probiotics most subjects had a considerable reduction in markers of metabolic stress and reported less emotional problems.

In this study, it was demonstrated that metabolic correction of biochemical disturbances using essential fatty acids, amino acids, and minerals can improve fatty acid profiles and metabolic stress levels. These disturbances or variations from reference values have been associated with behavior typical of ADHD.

Further studies need to be conducted with integrative metabolic correction therapy to determine its value in the management of ADHD. 
Competing interests: None of the authors has conflicting interest in this program.

Authors' contribution: NM and RH designed the study; NM, AR, and PT collected and analyzed the data; all authors contributed to interpretation of data and reviewed the manuscript.

Acknowledgements: The study was supported by Allan P Markin.

\section{REFERENCES:}

1. Scahill L, Schwab-Stone M. Epidemiology of ADHD in school-age children. Child Adoles Psychiat Clin N Am 2000; 9: 541-55.

2. Boyle MH, Offord DR, Racine Y, Sanford M, Szatmari P, Fleming JE. Evaluation of the original Ontario Child Health Study scales. Can J Psychiatry 1993; 38: 397-405.

3. Breton JJ, Bergeron L, Valla JP, Berthiaume C, Gaudet N, Lambert J, St Georges M, Houde L, Lepine S. Quebec child mental health survey: prevalence of DSM-III-R mental health disorders. J Child Psychol Psychiat 1999; 40: 375-384.

4. Rowland AS, Lesesne CA, Abramowitz AJ. The epidemiology of attentiondeficit/hyperactivity disorder (ADHD): a public health view. Ment Retard Dev Dis Res Rev 2002; 8: 162-170.

5. Association AP. Attention deficit hyperactivity disorder. In Diagnostic and Statistical Manual of Mental Disorders, Fourth Edition, Text Revision (DSM-IV-TR) Arlington, VA, American Psychiatric Association; 2000

6. Harding KL, Judah RD, Gant C. Outcome-based comparison of Ritalin versus foodsupplement treated children with AD/ HD. Altern Med Rev 2003; 8: 319-330.

7. Richardson AJ, Puri BK. The potential role of fatty acids in attentiondeficit/hyperactivity disorder. Prostaglandins Leukot Essent Fatty Acids 2000; 63: 79-87.

8. Asherson P. The IMAGE Consortium: Attention-deficit hyperactivity disorder in the post-genomic era. Eur Child Adoles Psychiat 2004; 13: 50-70.

9. Faraone SV, Perlis RH, Doyle AE, Smoller JW, Goralnick JJ, Holmgren MA, Sklar P. Molecular genetics of attention-deficit/hyperactivity disorder. Biol Psychiatry 2005; 57: 1313-1323.

10. Wurtman R, O'Rourke D, Wurtman JJ. Nutrient imbalances in depressive disorders. Possible brain mechanisms. Ann N Y. Acad Sci 1989; 575: 75-82.

11. Salem N Jr, Litman B, Kim HY, Gawrisch K. Mechanisms of action of docosahexaenoic acid in the nervous system. Lipids 2001; 36: 945-959.

12. Quist JF,Kennedy JL. Genetics of childhood disorders: XXIII.ADHD, part 7. The serotonin system. J Am Acad Child Adoles Psychiat 2001; 40: 253-256.

13. Raz R, Gabis L. Essential fatty acids and attention-deficit-hyperactivity disorder: A systematic review. Develop Med \& Child Neurol 2009; 51: 580-592.

14. Stevens LJ, Zentall SS, Abate ML, Kuczek T, Burgess JR. Omega-3 fatty acids in boys with behavior, learning, and health problems. Physiol Behav 1996; 59: 915-20.

15. Antalis CJ, Stevens LJ, Campbell M, Pazdro R, Ericson K, Burgess JR. Omega-3 fatty acid status in attention-deficit/hyperactivity disorder. Prostaglandins Leukot Essent Fatty Acids 2006; 75: 299-308. 
16. Burgess JR, Stevens L, Zhang W, Peck L. Long-chain polyunsaturated fatty acids in attention-deficit hyperactivity disorder. Am J Clin Nutr 2000; 71(suppl): 327S-330S.

17. Chen JR, Hsu S, Hsu C, Hwang L, Yang S. Dietary patterns and blood fatty acid composition in children with attention-deficit hyperactivity disorder in Taiwan. J Nutr Biochem 2004; 15: 467-472.

18. Colter AL, Cutler C, Meckling KA. Fatty acid status and behavioural symptoms of attention deficit hyperactivity disorder in adolescents: a case-control study. Nutr J 2008; 7: 8 .

19. Lorente AM, Jensen CL, Voigt RG, Fraley JK, Berretta MC, Heird WC. Effect of maternal docosahexaenoic acid supplementation on postpartum depression and information processing. Am J Obstet Gynecol 2003; 188: 1348-1353.

20. Krabbendam L, Bakker E, Hornstra G, van Os J. Relationship between DHA status at birth and child problem behaviour at 7 years of age. Prostaglandins Leukot Essent Fatty Acids 2007; 76: 29-34.

21. Hibbeln JR, Davis JM, Steer C, Emmett P, Rogers I, Williams C, Golding J. Maternal seafood consumption in pregnancy and neurodevelopmental outcomes in childhood (ALSPAC study): an observational cohort study. Lancet 2007; 369: 578-585.

22. Brookes KJ, Chen $\mathrm{W}, \mathrm{Xu} \mathrm{X}$, et al. Association of fatty acid desaturase genes with attention-deficit/hyperactivity disorder. Biol Psychiatry 2006; 60: 1053-1061.

23. Cory-Slechta DA, Weiss B. Efficacy of the chelating agent CaEDTA in reversing leadinduced changes in behavior. 1988; 246(1): 84-91.

24. Martinez EJ, Kolb BL, Bell A, Savage DD, Allan AM. Moderate perinatal arsenic exposure alters neuroendocrine markers associated with depression and increases depressive-like behaviors in adult mouse offspring. Neurotoxicology 2008; 29(4): 647655.

25. Yorbik O, Kurt I, Hasimi A, Oztürk O. Chromium, cadmium, and lead levels in urine of children with autism and typically developing controls.Bio Trace Element Res 2010; 135: 10-15.

26. Institute for Children's Environmental Health [http://www.iceh.org/pdfs/LDDI/LDDIStatement.pdf]

27. Palmer R, Blanchard S, Stein Z, Mandell D, Miller C. Environmental mercury release, special education rates, and autism disorder: an ecological study of Texas. Health Place 2006, 12:203-209.

28. Jin Y, Xi S, Li X, Lu C, Li G, Xu Y, Qu C, Niu Y, Sun G. Arsenic speciation transported through the placenta from mother mice to their newborn pups. Environ Res 2006; 101(3): 349-355.

29. Cory-Slechta DA, Virgolini MB, Rossi-George A, Thiruchelvam M, Lisek R, Weston D. Lifetime Consequences of Combined Maternal Lead and Stress. Basic \& Clin Pharmacol \& Toxicol 2008; 102: 218-227.

30. Colomina MT, Roig JL, Torrente M, Vicens P, Domingo JL. Concurrent exposure to aluminum and stress during pregnancy in rats: Effects on postnatal development and behavior of the offspring. Neurotoxicol Teratol 2005; 27(4): 565-74. 
31. Toren P, Elder S, Sela BA, Wolmer L, Weitz W, Inbar D, Koren S, Reiss A, Weizman R, Laor N. Zinc deficiency in attention deficit hyperactivity disorder. Biol Psychiat 1996; 40: 1308-1310.

32. Bekarglu M, Aslan Y, Gedik Y, Deger O, Mocan H, Erduran E, Karahan C. Relation between serum free fatty acids and zinc, and attention deficit hyperactivity disorder: A research note. J Child Psychol Psychiat 1996; 37: 225-227.

33. Bilici M, Yildirim F, Kandil S, Berkaroglu M, Yildirmis S, Deger O, Ulgen M, Yildiran A, Aksu H. Double blind, placebo-controlled study of zinc sulfate in the treatment of attention deficit hyperactivity disorder. Prog Neuropsychopharm \& Biol Psychiat 2004; 28: 181-190.

34. Mousain-Bosc M, Roche M, Rapin J, Bali JP. Magnesium VitB6 Intake Reduces Central Nervous System Hyperexcitability in Children. J Am Coll Nutr 2004; 23(5): 545S-548S.

35. Bac P, Maurois P, Dupont C, Pages N, Stables JP, Gressens P, Evrard P, Vamecq J. Magnesium deficiency-dependent audiogenic seizures (MDDASs) in adult mice: a nutritional model for discriminatory screening of anticonvulsant drugs and original assessment of neuroprotection properties. J Neurosci 1998; 18: 4363-4373.

36. Kozielec T, Starobrat-Hermelin B. Assessment of magnesium levels in children with attention deficit hyperactivity disorder (ADHD). Magnes Res 1997; 10:143-148.

37. Starobrat-Hermelin B, Kozielec T. The effects of magnesium physiological supplementation on hyperactivity in children with attention deficit hyperactivity disorder (ADHD). Positive response to magnesium oral loading test. Magnes Res 1997; 10: 149156.

38. 38.Gant C. Complementary medicine approaches to ADHD. Presentation to Annual Conference, American College of Advancement in Medicine (ACAM), Orlando, FL, May 1999; Laguna Hills, CA, ACAM, 1999.

39. Gant C, Harding K, Judah R. ADD and ADHD Pilot Research Projects. East Syracuse, NY: Charles Gant, MD, PhD; 1999.

40. Kidd PM. Attention Deficit/Hyperactivity Disorder (ADHD) in Children: Rationale for Its Integrative Management. Altern Med Rev 2000; 5: 402-421.

41. Irvine DG. Apparently non-indolic Erhlich-positive substances related to mental illness. J Neuropsychiatr 1961; 2: 292-305.

42. Hoffer A. The presence of malvaria in some mentally retarded children. Am J Ment Defic 1963; 67: 730-732.

43. Hoffer A. The discovery of kryptopyrrole and its importance in diagnosis of biochemical imbalances in schizophrenia and in criminal behavior. J Orthomolec Med 1995; 10: 3-7.

44. Graham DJM. Quantitative determination of 3-Ethyl-5-hydroxy-4,5 dimethyl $-\Delta 3-$ Pyrroline -2-one in urine using gas-liquid chromatography. Clin Chem Acta 1978; 85: 205-210.

45. McGinnis WR, Audhya T, Walch WJ, Jackson JA, McLaren-Howard J, Lewis A, Luda PH, Bibus DM, Jurnak F, Lietha R, Hoffer A. Discerning the mauve factor. Part 1. Altern therapies 2008; 14, 40-60.

46. McGinnis WR. Discerning the mauve factor. Altern therapies 2008; 14: 40-60. 
47. Irvine DG. Kryptopyrrole in molecular psychiatry. In: Hawkins D, Pauling L, eds. Orthomolecular Psychiatry: Treatment of Schizophrenia. San Francisco: WH Freeman and Company: 1973; 146-178.

48. 48.Irvine DG. Kryptopyrrole and other monopyrroles in molecular neurobiology. Int Rev Neurobiol. 1974; 16: 145-182.

49. Rao BS, Narayanan HS, Reddy GN. Investigations on urinary excretion of 3,4 dimethoxyphenylethylamine (the pink spot), the Mauve factor and aromatic compounds in patients with schizophrenia. Indian J Med Res. 1971; 59(3): 455-460.

50. Bourre JM. Effects of nutrients (in food) on the structure and function of the nervous system: update on dietary requirements for brain. Part 1: micronutrients. J Nutr Health Aging 2006; 10(5): 377-385.

51. Bonham M, O'Connor JM, Hannigan BM, Strain JJ. The immune system as a physiological indicator of marginal copper status? Br J Nutr. 2002,87(5):393-403.

52. 52. Toren P, Elder S, Sela BA, Wolmer L, Weitz R, Inbar D, Koren S, Reiss A, Weizman $\mathrm{R}$, Laor N. Zinc deficiency in attention deficit hyperactivity disorder. Biol Psychiat 1996; 40: 1308-1310.

53. Bekarglu M, Aslan Y, Gedik Y, Değer O, Mocan H, Erduran E, Karahan C. Relation between serum free fatty acids and zinc, and attention deficit hyperactivity disorder: A research note. J Child Psyhol Psychiat 1996; 37: 225-227.

54. Kirby K, Floriani V, Bernstein H. Diagnosis and management of attention deficit hyperactivity disorder in children. Curr Opinion Pediatr 2001; 13: 190-199.

55. Bilici M, Yildirim F, Kandil S, Bekaroğlu M, Yildirmiş S, Değer O, Ulgen M, Yildiran A, Aksu H. Double blind, placebo-controlled study of zinc sulfate in the treatment of attention deficit hyperactivity disorder. Prog in Neuropsychopharm and Biol Psychiat 2004; 28: 181-190.

56. Kozielec T, Starobrat-Hermelin B, Kotkowiak L. Deficiency of certain trace elements in children with hyperactivity. Psychiatr Pol 1994; 28(3): 345-353.

57. Yu WR, Jiang H, Wang J, Xie JX. Copper $(\mathrm{Cu} 2)$ induces degeneration of dopaminergic neurons in the nigrostriatal system of rats. Neurosci Bull 2008; 24(2): 73-78.

58. Shi LM, Jiang H, Wang J, Ma ZG, Xie JX. Mitochondria dysfunction was involved in copper-induced toxicity in MES23.5 cells. Neurosci Bull 2008; 24(2): 79-83.

59. Russo AJ. Decreased Serum Cu/Zn SOD Associated with High Copper in Children with Attention Deficit Hyperactivity Disorder (ADHD). J Central Nervous Sys Dis 2010; 2

60. Volkow ND, Wang GJ, Newcorn J, Telang F, Solanto MV, Fowler JS, Logan J, Ma Y, Schulz K, Pradhan K, Wong C, Swanson JM. Depressed Dopamine Activity in Caudate and Preliminary Evidence of Limbic Involvement in Adults With Attention-Deficit/ Hyperactivity Disorder. Arch Gen Psychiat 2007; 64(8): 932-940.

61. Volkow ND, Wang GJ, Kollins SH, Wigal TL, Newcorn JH, Telang F, Fowler JS, Zhu W, Logan J, Ma Y, Pradhan K, Wong C, Swanson JM. Evaluating Dopamine Reward Pathway in ADHD: Clinical Implications. JAMA 2009; 302: 1420-1429. 